88 フラットパネルディテクタ搭載乳房撮影装置の線量表示値の 検討 愛知県がんセンター・放射線診断部 服部寿史, 堀田勝平 名古屋大学医学部保健学科 小山修司/藤田保健衛生大学 前越 久 【目的】フラットパネルディテクタ搭載乳房撮影装置で測定表示され る照射線量值㧍よび平均乳腺線量值について実測值との比較を行っ た。

【方法】撮影条件およびファントム厚を变化させて照射線量を測定し た值から平均乳腺線量值を求め装置の測定表示值と比較した.

【結果】装置の設定にもよるが表示される照射線量值および平均乳腺 線量值はあくまでも理論值として算出されたものであり実際の実測 值とは若干の差は認められるものの被曝線量を把握するには充分な 機能であり被曝管理という点からも有効であると考えられた.

\section{9 フルフィールドディジタルマンモグラフィの照射線量とノイ} ズの関係

日本医科大学付属病院 - 放射線科谷越雅幸, 小林宏之, 増山桂一 鈴木智之, 黒田大介, 鈴木 健

【目的】2001年春期総会にてフルフィールドディジタルマンモグラ フィ(以下, FFDM) はスクリーンフィルムマンモグラフィ(以下, SFM) に対し鮮鋭性は劣るものの，粒状性が優れ，同等線量である 場合, 総合画質評価である $\mathrm{NEQ}(\mathrm{u})$ で優位であることを発表した。 今回, SFMと同等画質を維持したまま, FFDMが, どの程度まで撮 影線量を下げられるか，W.Sの測定と視覚評価にて検証した。

【方法】線量とノイズ特性の関係を把握するため, 線量変化時のW.S を測定した。 また，RM156およびCDMAMファントムを用いて視覚 評価を行った。

【結果】FFDMの線量が70％減少するとノイズは1.2倍，50\%減少する とノイズは1.4倍となる傾向にある，また，視覚評価に扔いて，SFM と同等な評価となる線量はFFDMで約 $70 \%$ 線量であり, W.Sとの結 果を照らし合わせることで撮影線量軽隇の可能性が示唆された。

90 二つのディジタルマンモグラフィシステムのノイズ特性 日本医科大学付属病院・放射線科 小林宏之, 谷越雅幸, 水谷光樹 吉田伸二郎·鈴木 健

【目的】現在，ディジタルマンモグラフィとして臨床応用されている 最新システムとしては, フルフィールドディジタルマンモグラフィ (以下, FFDM) と両面集光技術および20pixel/mmの画素密度を搭載 したFCR5000MAシステムがある。われわれは2001年の春総会にて FFDMシステムとスクリーン・フィルムマンモグラフィ (SFM)シス テムの画質比較を行ない，特にノイズ特性に差が認めた．今回は二 つのディジタルマンモグラフィシステムに扔けるノイズを中心とし た画質を評価したので報告する。

【方法】雨者のノイズ特性を把握するためにウィナースペクトルを測 定した。また，ノイズに関与する検出能を確認するため, CD-MAM ファントムによる評価も行った。

【結果】二つのディジタルマンモグラフィシステムにおけるCD-MAM ファントム評価に抢いては，ほぼ同程度であることが確認された。

91 乳房切除標本を用いたデイジタルマンモグラフィの視覚的評侕 筑波大学附属病院 湊 涼子

東京医科歯科大学医学部附属病院 横田 浩

筑波大学附属病院 千葉 登, 楠本敏博

【目的】放射線画像診断におけるデイジタル化の流れに沿うように, マンモグラフィの分野にも，フルフィールドディジタルマンモグラ フィ(FFDM)装置が開発された，FFDMによるマンモグラフィは，わ れわれの行った156ファントムを用いた画像評価において，フィル ム/スクリーンを用いた従来法(F/S法) と大きな差はなく，マンモグ
ラフィ検診精度管理中央委員会の基準も満たしていた，今回，石灰 化を有する乳癌症例を対象に, 全摘出された乳房を用いてマンモグ ラフィを撮影し, 得られた画像の視覚的評価と平均乳腺線量をF/S法 と比較したので報告する。

【方法】1) 手術前に患側乳芳のマンモグラフィ(MLO像のみ)をF/S 法, FFDMでオート撮影し, 画像を検討する，2)外科的手術により 全摘出された乳房をMLO像になるように圧迫し，オート撮影を行 い，その画像を検討する．圧迫の際，乳房愿は等しくなるようにす る. 3)平均乳腺線量を, 精度管理マニュアルに従って測定する。

【結果および結論】各マンモグラフィ上に認められる石灰化像の見兄 方を視覚的評価した結果, FFDMによるマンモグラフィはF/S法に比 ベて, 認められる石灰化像の形状によって, 描出は多少劣るもの の，臨床診断に影響するほどではなかった。また，平均乳腺線量を F/S法と比較すると, FFDMの方が若干多かった．今回は，オート撮 影モードで得られた画像を比較したが，ディジタル処理を行える FFDMでは，少ない線量で同等の画像を得られると思われる。

92 screen-film mammography とdigital mammographyの検出能の 比較

日本医科大学付属千葉北総病院·中央画像検査室 吉澤賢史，田村 京 日本医科大学付属病院 - 放射線科 小林宏之, 鈴木智之, 黒田大介 増山桂一, 鈴木 健

【目的】マンモグラフィ検查領域に执いて，ディジ夕ル化の導入が進 むなか，その有効性については慎重に議論をする必要がある。今 回，われわれはGE社製フルフィールドデジタルマンモグラフィーシ ステム(Senographe2000D), 富士フイルム社製 (FCR5000MA) とスク リーンノイルムシステムにおける異なる三つのシステムを比較し， 乳房用ファントムを用いて検出能の違いを検討した.

【方法】1. 各システムに招ける処理条件の調整. 2. 乳房用ファント ム $($ RMI156, CDMAM)を用いた腫瘤, 線維組織, 石灰化の評価. 3. 乳腺組織等により重なったX線高吸収部位での石灰化検出.

【結果・考察】今回，フラットパネル型ディテクタを有する Senographe2000D扝よび微小石灰化の形状診断などで問題となる画素 サイズを縮小したFCR5000MAの 2 種類のディジタル系, さらに有 効性が確認されているスクリーンハィルムを使用したアナログ系の 異なるシステムについて検討しそれぞれの特徵について把握するこ とができた．特に乳腺組織が重なった部位での描出能でその違いを 把握することができ, 石灰化の検出能においてもそれぞれの特徽が あることが確認できた。

\section{3 滕関節側面完全伸展位撮影法の検討}

金沢大学医学部附属病院 ·放射線部 間島郁子, 木津寬人, 布施真至 野村孝之，山本友行，松井武司，西村 奨，田村鋒男

【目的】当院の整形外科では前十字靱帯 $(\mathrm{ACL})$ を損傷し再建術を執行 した患者のフォローアップとして膝関節側面完全伸展位撮影法を 行っている．この撮影はブルメンザッツラインとティビアトンネル (脛骨にあけた穴) との位置を計測するため，大腿骨内・外顆の重な りを上下左右 $6 \mathrm{~mm}$ 以内に收めなければならない。そこでわれわれは 撮影補助具を作成し, 正確な滕関節側面完全伸展位の撮影法を検討 したので報告する。

【撮影方法】1) 検側の下腿骨軸を $6^{\circ}$ 内転さ也る，2）滕蓋骨下部の両縁 下方の大腿骨内 - 外側顆前縁に試作の撮影補助具の再先端を強く押 しつける, 補助具附属の角度計ないし水準器を用い, 先端を結ぶ線 がフィルムに対し垂直になるように大腿骨を内・外旋させる。3)溙 関節中央を照射野中心とし撮影する。4)撮影した画像より内・外側 顆の上下左右のズレを測定し今回の撮影法を検討した.

【結果】当院の放射線技師数名に扮ける測定結果では，上下のズレが 平均 $1 \mathrm{~mm}$ 以下, 左右のズレは平均 $2 \mathrm{~mm}$ であった。 